\title{
Effect of LPS, dsRNA or interferons on the phagocytosis of dying cells or mycobacteria by macrophages
}

\author{
Frederic Vanzembergh ${ }^{1 *}$, Greet Brouckaert ${ }^{1,2}$, Florence Nazé ${ }^{1}$, Steven Van Gucht ${ }^{1}$, Tom Vanden Berghe ${ }^{2}$, \\ Dmitri Krysko ${ }^{2}$, Peter Vandenabeele ${ }^{2}$, Michael Kalai ${ }^{1}$ \\ From Institut Pasteur International Network Annual Scientific Meeting \\ Hong Kong. 22-23 November 2010
}

Infection with intracellular pathogens can trigger a panel of innate immune responses including cell death. Coupled with phagocytosis this often leads to clearance of the invader. However, some pathogens use the process to disseminate and proliferate. During Mycobacterium marinum infection, dying infected macrophages recruit fresh ones to the site of granuloma formation. The recruited macrophages phagocytose infected cell remnants, get infected and die, thus ensuring efficient spread and multiplication of the pathogen. Maturation of granuloma, the characteristic lesions of tuberculosis, requires tumor necrosis factor (TNF) and interferon (IFN)-gamma and represents a stalemate between host and pathogen sufficient to arrest infection without eliminating the bacteria. Indeed, our macrophage / mycobacterial infection model demonstrates that virulent H37RvMycobacterium tuberculosis is more efficient in macrophage infection and killing than the attenuated Mycobacterium bovis BCG vaccine.

Today it is still unclear whether the signal promoting macrophage engagement in phagocytosis is originating from a pathogen or the infected host, and whether the effect is general or target specific. Therefore, we used a quantitative cell line based assay to study the effects of PAMPs or cellular alarm signals on the phagocytic engagement and capacity of macrophages to engulf virulent or attenuated mycobacteria and dying cells. Our results demonstrate that pretreatment of macrophage like cells with double stranded RNA, lipopolysaccharide, type I or II IFN but not with TNF, can significantly increase their capacity to phagocytose apoptotic and

${ }^{1}$ Communicable and infectious diseases, Scientific Institute of Public Health, 1180 Brussels, Belgium

Full list of author information is available at the end of the article necrotic cells but has little effect on the phagocytosis of free mycobacteria. Although this macrophage activation process is probably an innate immune response reinforcing the capacity of the host to dispose of dying infected cells, pathogens may exploit it for their propagation.

\section{Author details}

${ }^{1}$ Communicable and infectious diseases, Scientific Institute of Public Health, 1180 Brussels, Belgium. ${ }^{2}$ Molecular Signaling and Cell Death Unit,

Department for Molecular Biomedical Research, VIB and Department of Biomedical Molecular Biology, Ghent University, 9052 Zwijnaarde, Belgium.

Published: 10 January 2011

doi:10.1186/1753-6561-5-S1-P82

Cite this article as: Vanzembergh et al.: Effect of LPS, dsRNA or interferons on the phagocytosis of dying cells or mycobacteria by macrophages. BMC Proceedings 2011 5(Suppl 1):P82.

Submit your next manuscript to BioMed Central and take full advantage of:

- Convenient online submission

- Thorough peer review

- No space constraints or color figure charges

- Immediate publication on acceptance

- Inclusion in PubMed, CAS, Scopus and Google Scholar

- Research which is freely available for redistribution

\section{Biomed Central}

